\title{
KAKO (JE) TVORNICA MIJENJA(LA) GRAD: PRIMJER TVORNICE DALMATINKA
}

Izvorni znanstveni članak Primljeno: 24. 7. 2018. Prihvaćeno: 17. 10. 2018. DOI: $10.15176 /$ vol55no206 UDK 338.45(497.538Sinj)(091)

\author{
DRAGANA MODRIĆ \\ Galerija Sikirica, Sinj
}

\begin{abstract}
Sredinom prošloga stoljeća otvaranje Tvornice i predionice konca Dalmatinka u izrazito nerazvijenom ruralnom području Dalmatinske zagore označilo je svojevrsnu industrijsku i kulturnu revoluciju. Sinjska Dalmatinka će tijekom godina postati jedna od najuspješnijih tekstilnih tvornica jugoistočne Europe. Tvornica je neposredno doprinijela jačanju lokalnog gospodarstva i inicirala procese društvene i urbanističke preobrazbe grada. Od samog početka provodila je politiku stambenog zbrinjavanja radnika, što je bitno utjecalo na urbanističku sliku Sinja. Na primjeru tvornice može se iščitati povijest radništva, stambene politike, infrastrukturnog razvoja grada te važnih društvenih fenomena poput ženske emancipacije. U tekstu će se analizirati rezultati istraživanja koje je provedeno u okviru projekta Industrijsko nasljeđe i kultura sjećanja na primjeru tvornice Dalmatinka - Sinj te naznačiti mogućnost iščitavanja projekta u kontekstu uspostave političkog u prostoru umjetnosti, kao važnog elementa $u$ angažiranju publike/zajednice.
\end{abstract}

Ključne riječi: Sinj, Dalmatinka, industrijska baština, političko, društveno angažirane umjetničke prakse

UVOD

Ne postoji stvaran svijet izvan umjetnosti.

Jacques Rancière

Projekt "Industrijsko nasljeđe i kultura sjećanja na primjeru tvornice Dalmatinka - Sinj" (kasnije u tekstu projekt Dalmatinka)' iniciran je s ciljem revalorizacije povijesnog nasljeđa socijalizma, kojemu tvornica Dalmatinka povijesno i društveno pripada, a koje je, namjerno ili ne, u sjećanju zajednice (bilo) potisnuto i zaboravljeno. Projekt je od početka imao

${ }^{1}$ Projekt su pokrenuli Nikola Križanac, Jelena Pavlinušić i Dragana Modrić. 
političku konotaciju jer se istraživala zlatna povijest tvornice iz perioda socijalizma, inače prešućenog perioda lokalne povijesti. Rezultati istraživanja pokazali su izniman utjecaj tvornice na podizanje kvalitete života ljudi u Cetinskom kraju. Tvornica je kroz edukacije i stručno obrazovanje izravno doprinijela opismenjavanju stanovništva, poboljšao se zdravstveni standard, procvjetao je kulturni i sportski život. Zahvaljujući sustavnoj stambenoj politici zbrinjavanja radnika osviještena je kultura stanovanja u gradu i stubokom je izmijenjena urbanistička slika grada Sinja. Nakon privatizacije i stečaja tvornice, radnici gotovo preko noći postaju višak, kako u tvornici tako i društvu, te postaju društveno marginalizirana skupina. U projekt su se, kroz različite forme - intervjue, razgovore, radionice, izložbu - uključivali bivši radnici/e, a njihova su se sjećanja pokazala iznimno važnima za razumijevanje radničke povijesti Sinja.

Rezultati istraživanja prezentirani su putem izložbe, u javnom prostoru, čime je Dalmatinka, zajedno s pitanjima lokalne radničke prošlosti, ženske emancipacije, urbanizacije grada, privatizacije i deindustrijalizacije, ušla u umjetnički i javni diskurs. Time je kreiran prostor moguće promjene, političke subjektivizacije bivših radnika, ali i cjelokupne lokalne zajednice grada Sinja.

U tekstu se postavlja teza o uspostavi prostora političkog, onako kako ga definiraju Jacques Rancière (2010) i Chantal Mouffe (2016), kao potencijalno društveno angažirajućeg momenta. Pojam političkog preuzima se iz filozofije politike te se oslanja na teoriju hegemonije i povezanih pojmova antagonizma i neslaganja (dissensus). Umjetničke prakse koje se bave društvenim pitanjima često u svojoj osnovi posjeduju želju za promjenom postojećeg društva. Promjena je moguća ukoliko se uspostavi (politički) prostor unutar kojeg se, putem antihegemonijskih praksi, dekonstruira postojeći sustav i uspostavi nova forma hegemonije (Mouffe 2008). Uspostava političkog kao prostora neslaganja i konfrontacije u javnom prostoru, moguća je i u političkoj i u umjetničkoj praksi (Rancière 2010). Ovako shvaćen pojam političkog pokazao se koristan pri analizi društveno angažiranih umjetničkih praksi/projekata. To će se potvrditi i na primjeru istraživanja tvornice Dalmatinka, o čemu će biti riječ dalje u tekstu.

U prvom dijelu teksta iznose se rezultati istraživanja koji ukazuju na značajan doprinos tvornice društvenom kapitalu zajednice (obrazovanje, emancipacija žena, stambena politika), dok se u drugom dijelu teksta analizira politički potencijal projekta u polju umjetnosti.

\section{O TVORNICI}

Tvornica i predionica konca Dalmatinka započinje s radom pedesetih godina prošlog stoljeća u poratnom Sinju, sredini bez tradicije u bilo kakvoj industrijskoj proizvodnji, kamoli zahtjevnoj kao što je u to vrijeme bila tekstilna. Odluka o gradnji tvornice donesena je 1946. godine i u potpunosti je promijenila sliku dotad ekonomski izrazito nerazvijenog sinjskog kraja. Tvornica je započela s preradom pamučne pređe sa svega 150 radnika, da 
bi vrlo brzo prerasla u tekstilnog diva koji je na vrhuncu, sedamdesetih godina, zapošljavao preko 2500 radnika. Dalmatinka je zadovoljavala 65 posto potreba bivše Jugoslavije za pamučnom pređom i koncem. Osim toga, tvornica je izvozila konac diljem Europe, pa čak i na afrički i azijski kontinent (Burma, Alžir, Iran). ${ }^{2}$ Kao i brojne druge tvornice u tom razdoblju, provodila je politiku stambenog zbrinjavanja radnika putem povoljnih kredita ili izgradnjom stambenih objekata (dodjelom stanova), što je bitno utjecalo na urbanizaciju grada Sinja i okolice. Dalmatinka je financirala i izgradnju gradskog bazena olimpijskih dimenzija, koji je Sinj dobio već 1953. godine. Dalmatinka je bila i osnivač brojnih sportskih i kulturnih društava, koja su nakon propasti tvornice nastavila sa svojim djelovanjem. Tvornica je imala odmarališta za radnike, ljetovalište u Strožancu i kuću za odmor na obližnjem jezeru Peruća. Bila je pokretač lokalne ekonomije, društvenog i urbanističkog razvoja grada. Promjenom političkog, ekonomskog i društvenog okvira, tvornica prolazi bolan tranzicijski proces privatizacije, koji završava stečajem i prosvjedima radnika. Premije, dodatke na plaću, besplatan obrok, subvencioniranje ljetnog odmora kao i brigu o stambenom pitanju i zdravstvenoj skrbi zamijenili su borba radnika za golu egzistenciju, neisplaćene plaće te omalovažavanje i ponižavanje na radnom mjestu. Sve je to utjecalo na potiskivanje sjećanja bivših radnika na rad i život u tvornici.

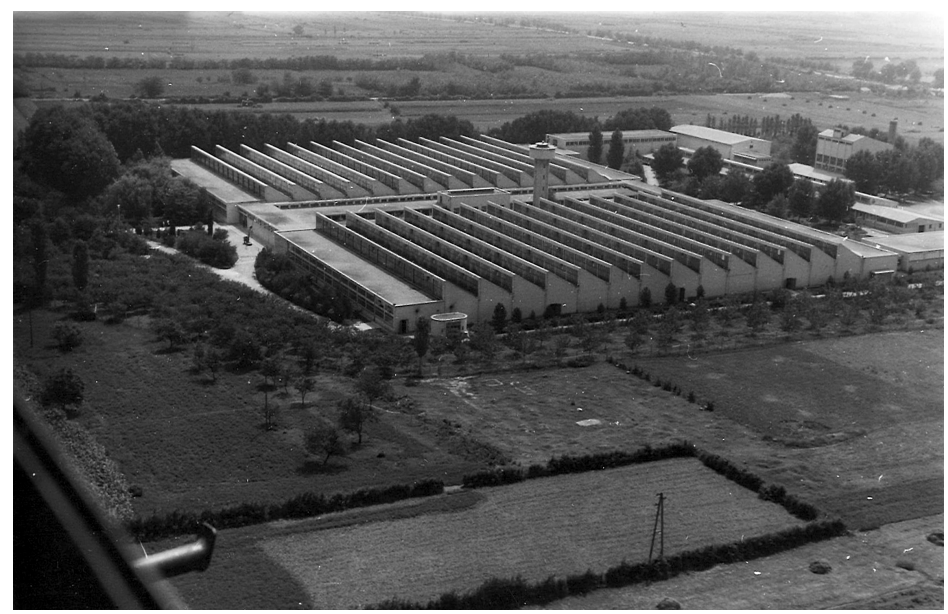

Pogled na Dalmatinku prije nadogradnji. Izvor: Muzej Cetinske krajine Sinj. Autor i godina nepoznati

\section{METODOLOGIJA ISTRAŽIVANJA}

U razdoblju od 2013. do 2018. godine sustavno je istraživana prošlost tvornice, način rada te društveni i kulturni utjecaj koji je Dalmatinka imala na grad Sinj i lokalnu zajednicu.

2 Podatak iz Spomen knjige u povodu proslave dvadesete godišnjice postojanja poduzeća Dalmatinka - predionice i tvornice konca Sinj: 1951.-1971. 
Tijekom terenskih istraživanja tvornice $u$ devastiranim prostorijama prikupljeni su materijali (uzorci) koji su kasnije analizirani i izloženi na izložbi u Galeriji Sikirica. ${ }^{3}$ S bivšim radnicama održano je nekoliko intervjua kojima se ispitivao utjecaj tvornice na modernizaciju i emancipaciju žena u Cetinskom kraju. ${ }^{4} \mathrm{U}$ formi video zapisa dokumentirana su kazivanja bivših radnika i slučajnih prolaznika, iz kojih je vidljiva snažna prisutnost Dalmatinke u kolektivnoj svijesti lokalnog stanovništva.

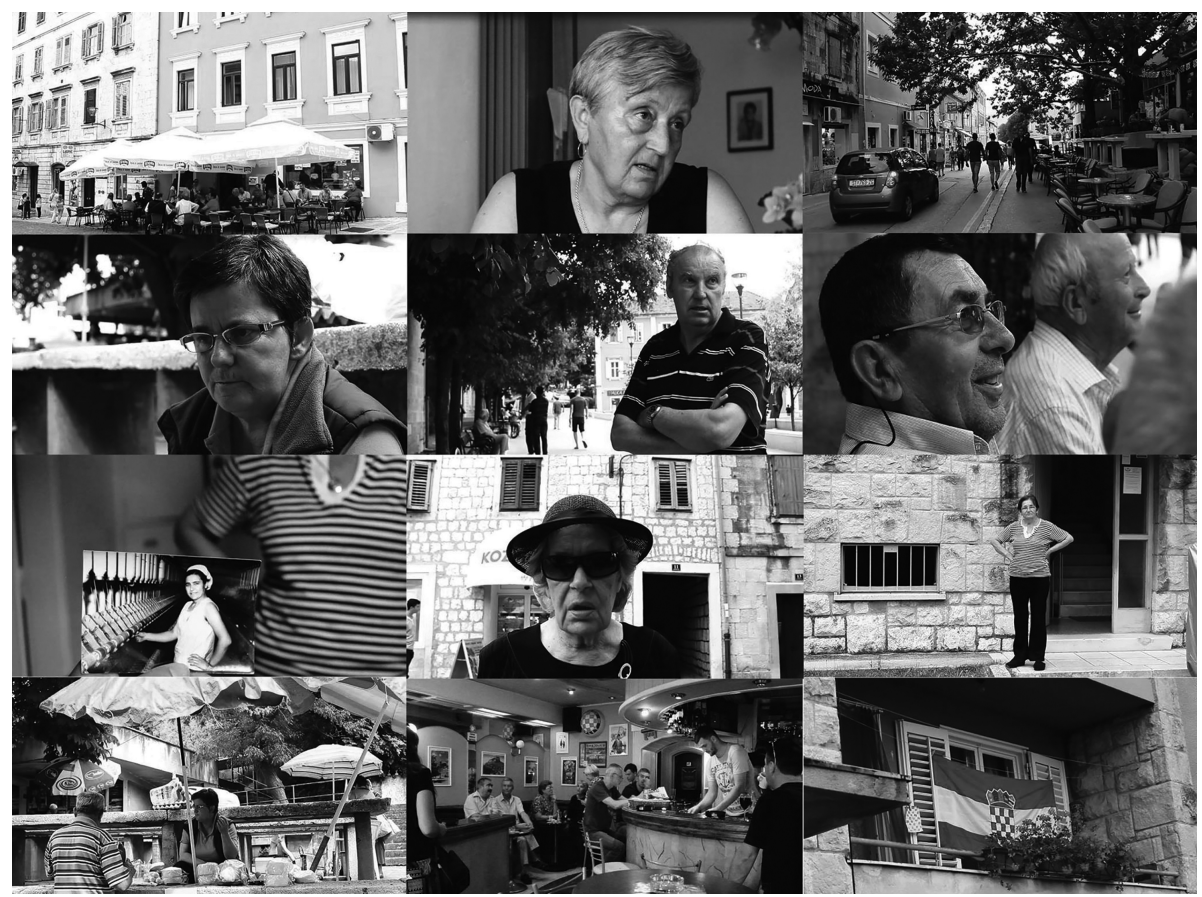

Isječci iz video intervjua s bivšim radnicima i slučajnim prolaznicima, 14. 6. 2014.

U sklopu projekta provedeno je i opsežno istraživanje Dalmatinkinih spisa koji se nalaze u Državnom arhivu u Splitu, kojim se dobio uvid u uvjete stanovanja u Sinju pedesetih godina prošlog stoljeća. ${ }^{5}$ Rezultati provedenog istraživanja prezentirani su u formi izložbe pod nazivom "Što je nama naša Dalmatinka dala?" u Galeriji Sikirica. Istraživanje je nastavljeno i za vrijeme trajanja izložbe, tijekom koje su se bilježili dojmovi bivših radnika i njihova sjećanja povezana s različitim aspektima rada u tvornici. ${ }^{6}$ Uz izložbu je tiskana

\footnotetext{
${ }^{3}$ Prikupljeni materijali odnose se na bilježnice s komentarima koje su vodili vođe smjena, dokumentaciju iz restorana, umjetničke slike, uzorke konca, plakete, fotografski materijal.

${ }^{4}$ Sociologinja Silvia Milić provela je deset dubinskih intervjua s bivšim radnicama koji se nalaze u arhivi Galerije Sikirica.

${ }^{5} \mathrm{U}$ okviru projekta ostvarena je institucionalna suradnja s nekoliko muzeja: Muzejom Jugoslavije iz Beograda, Tehničkim muzejom Nikola Tesla iz Zagreba, Muzejom Cetinske krajine te Državnim arhivom u Splitu.

${ }^{6}$ Dojmovi bivših radnika Dalmatinke dostupni su u elektroničkom zapisu u Galeriji Sikirica.
} 
i publikacija istog naslova koja obuhvaća nekoliko tekstova relevantnih za razumijevanje Dalmatinke u širem društvenom kontekstu. Neki od tekstova već su prethodno objavljeni i predstavljaju referentnu točku za istraživanje povijesti tvornice i s njom usko povezane ženske povijesti (Premuž Đipalo 2016; Paladino 2013), dok su drugi napisani za potrebe ili u sklopu istraživanja (Bonfiglioli 2017; Magdić 2017; Pavlinušić 2017).

U okviru projekta kreirana je Facebook stranica, koja ima dvostruku funkciju: promociju svih aktivnosti povezanih s projektom i prikupljanje podataka koji se tiču tvornice i radnika. Stranica bilježi pozitivne statistike i značajne reakcije (dostupno na https://web.facebook. com/dalmatinkasinj/)?

\section{REZULTATI I RASPRAVA}

\section{OBRAZOVANJE I EMANCIPACIJA RADNIKA}

Nakon što su stvoreni minimalni uvjeti, 20. rujna 1952. godine, počeo je s radom prvi pogon Dalmatinke. Time je i službeno otpočela industrijalizacija nerazvijenog Cetinskog kraja, koji će u narednom razdoblju doživjeti ekonomski i društveni procvat. Od početka izgradnje do proizvodnje u pogonu Predionice prošle su svega dvije godine, što predstavlja svojevrsni kuriozitet uzmemo li u obzir da se tvornica gradila u kraju bez ikakve tradicije u proizvodnji pamučnog češljanog prediva i konca. Detalji vezani za prve godine rada važni su za shvaćanje uloge tvornice u promjeni dotadašnjeg načina života stanovnika Sinja i Cetinskog kraja, posebno žena. Svjedočanstvo o volji radnika za napretkom (radom, obrazovanjem) donosi nam sljedeći iskaz radnika:

Nediljko je bio jedan od prvih radnika Dalmatinke koji je pedesete godine poslan na obučavanje u Dugu Resu. lako je bio nepismen, brzo je shvatio princip rada strojeva na kojima je proveo cijeli svoj radni vijek. Bio je majstor, a kasnije, kaže, osamdesetih, čak i predsjednik Sindikata. Još uvijek čuva ključ koji su mu Englezi dali za popravljanje strojeva, s kojima je mogao odvidati većinu vida. (Iz Dnevnika dojmova, Galerija Sikirica, 27. 11. 2017.)

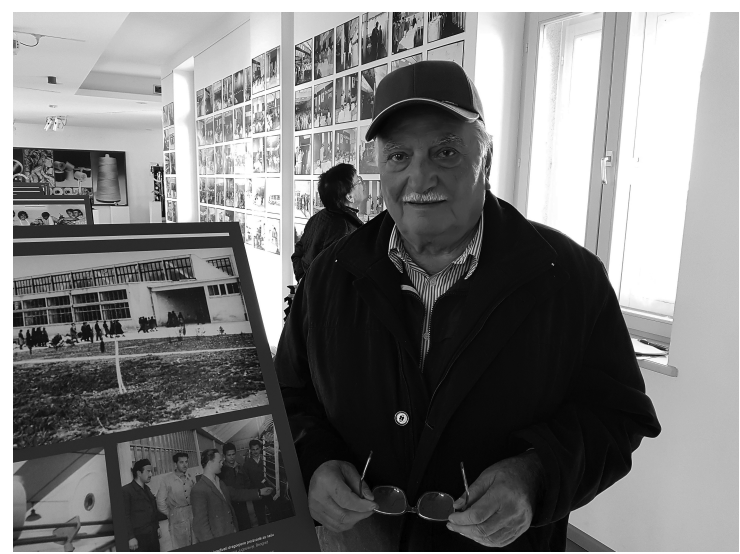

Radnik Dalmatinke Nediljko Ančić prilikom posjeta izložbi "Što je nama naša Dalmatinka dala?", pored fotografije s kolegama iz pedesetih godina. Fotografirala Dragana Modrić, 4. 12. 2017.

7 Putem medija su u nekoliko navrata pozivani radnici na sudjelovanje. Odaziv je bio jako dobar te su na taj način prikupljeni vrijedan fotografski materijal i dokumentacija. Sav prikupljeni materijal bit će nakon stručne obrade digitaliziran i dostupan svim zainteresiranima. 
Kako bi se obučili za rad u tvornici, radnici odlaze u gradove s tradicijom tekstilne industrije, Maribor, Kranj, Dugu Resu. Svaki obučeni radnik bio je iznimno važan, o čemu svjedoči prepiska direktora Dalmatinke, Miloša Stanojevića, u kojoj traži odgodu odsluženja zatvorske kazne za jednog od radnika/montera, optuženog zbog ilegalnog prelaska granice, dok ne završi montažu strojeva koju je započeo. ${ }^{8}$

Zahvaljujući velikom entuzijazmu i pokazanim sposobnostima, radnici Dalmatinke u kratkom vremenu preuzimaju sve poslove oko montaže strojeva, što je znatno ubrzalo početak proizvodnje, a kasnije i održavanje mehanizacije. ${ }^{9} \mathrm{O}$ elanu radnika čitamo i u novinama: "Nije nam smetalo što smo radili u ogromnoj hali bez grijanja, najčešće gladni, i što je radni dan trajao 10, 12 i više sati. U takvim uvjetima smo se natjecali tko će napraviti više i bolje" (s. n. 1981).

Radnici prve generacije većinom su bili nepismeni, stoga tvornica pokreće aktivnu politiku opismenjavanja koja se provodila putem tečajeva i dodjelom stipendija, a kasnije i otvaranjem školskih odjeljenja. U početku je bilo teško motivirati radnike za učenje, stoga tvornica uvodi promjene u tarifni pravilnik. Radnici koji nisu imali položen ispit zarađivali su šest dinara manje po satu od onih radnika koji su ga položili. ${ }^{10}$ Zahvaljujući Dalmatinki 1954. godine osnovana je Industrijska tekstilna škola u Sinju te večernja škola za radnike tekstilne struke. U okviru tvornice osniva se Tvornički centar za stručno obrazovanje radnika (1960.), a organizirani su i dvogodišnji tečajevi za učenje engleskog i njemačkog jezika u suradnji sa školom stranih jezika iz Splita. Put koji su nepismeni radnici prošli od poljoprivrednika do obučenih tekstilaca, lakše se odvijao zahvaljujući prvenstveno obrazovnim politikama tvornice, što se u konačnici reflektiralo i na poslovni uspjeh.

Unatoč egalitarističkom stavu socijalističke ideologije i službenoj politici koja je promicala ravnopravnost spolova, položaj žene u ruralnim krajevima Dalmatinske zagore bio je daleko od proklamirane ravnopravnosti. Otvaranjem Dalmatinke žene prvi put stječu priliku za masovnije zapošljavanje u tim krajevima. Ipak, prijelaz iz privatne u javnu sferu rada nije bio nimalo lagan. Ženin odlazak od kuće zbog rada u tvornici dugo se smatrao nemoralnim činom. Prve generacije radnica bile su osuđivane i optuživane od okoline za nečasno ponašanje, zbog čega su neke dale i otkaz. Radnice se prisjećaju kako su prolaznici pljuvali za njima i nazivali ih pogrdnim imenima. ${ }^{11}$ Odlazak na obučavanje u drugi grad također se smatrao nemoralnim, o čemu svjedoči podrugljivo intonirana pjesma koje se prisjeća jedna od radnica: "Duga Resa, Duga Resa, bi li mesa?"12

${ }^{8}$ DARH-ST; Dalmatinka, Spisi 1/I,II (1951.- 1953.).

${ }^{9}$ Zbog nedostatka domaćeg stručnog kadra, montažu tvorničkih strojeva obavljali su engleski monteri, uz pomoć lokalnih radnika. O dolasku trojice engleskih radnika montera saznajemo iz prepiske glavnog direktora s Glavnom direkcijom tekstilne industrije Zagreb (DARH-ST, Dalmatinka, Spisi 1//,II (1951.-1953.).

${ }^{10}$ Iz Zapisnika Skupštine Sindikata.

${ }^{11} \mathrm{U}$ sklopu istraživanja Dalmatinke obavljeno je nekoliko intervjua i neformalnih razgovora s bivšim radnicama Dalmatinke. Sva prikupljena dokumentacija i snimljeni materijal nalaze se u arhivi Galerije Sikirica.

${ }^{12}$ Dio intervjua s N. V., bivšom radnicom Dalmatinke. Zapis dostupan u arhivi Galerije Sikirica. 
U početku rada tvornice nije postojao organizirani prijevoz, stoga su žene koje su živjele na selu morale pješačiti i po nekoliko desetaka kilometara do tvornice. Kako bi im se olakšalo, tvornica šezdesetih godina kupuje bicikle, što je ponovno naišlo na osudu okoline. Dio radnica relativno je brzo preuzeo građanski način odijevanja i ponašanja, ali kod većine je proces tekao sporo. Žene nisu imale usvojene higijenske navike, stoga tvornica u sklopu zdravstvene brige o radnicama uvodi redovne sastanke:

Održana su 4 sastanka sa svim ženama u svim smjenama po pitanju lične higijene žena, te im je ukazana štetnost i negativno utjecanje na zdravlje zapuštene žene, kao i posljedice u kolektivu koje snosi zbog aljkavosti i zapuštenosti nemarnih žena. (Referat 1960)

Dalmatinka je osnivač i pokretač prvih sportskih i kulturnih društava. Radničko sportsko društvo Tekstilac osnovano je s ciljem "da sportom podigne kondiciju i radnu sposobnost u kolektivu, razvija drugarstvo i odgaja svoje članove onako kako od sportaša zahtijeva naša zajednica".13 U sklopu društva djelovale su sekcije nogometa, košarke, kuglanja, stolnog tenisa. Tvornica je osnovala i Kulturno umjetničko društvo Alkar koje je imalo folklornu i tamburašku sekciju. lako su žene poticane na veći društveni angažman i preuzimanje upravljačkih funkcija, brojke govore drugačije. Iz tvorničkih zapisa saznajemo kako je u spomenutom Društvu 1960. godine od ukupno 187 aktivnih članova samo 18 žena. ${ }^{14}$ Rad Društva žena, koje je djelovalo unutar tvornice, u svom izvještaju navodi kako "žene same sebe zapostavljaju, te nisu postigle onaj nivo kojega treba da ima socijalistička žena" (Referat 1960).

Ipak, s vremenom se situacija mijenja i zahvaljujući radu u tvornici te stjecanjem ekonomske neovisnosti dolazi do promjene položaja žene unutar obitelji, a zatim i u društvu. Kako primjećuje Vedrana Premuž Đipalo u tekstu "Žene u doba socijalizma" (2016), dogodio se pomak u ostvarivanju veće emancipacije sinjskih žena. ${ }^{15}$ Tomu u prilog govori i izjava jedne od radnica koja na sljedeći način odgovara na novinarsko pitanje o tome što je Dalmatinka dala radnicama:

Prije svega samostalnost i povjerenje u sebe, a to znači i raskidanje s iskonskim tradicijama podčinjenosti. Mislim da su se čak i one iz najudaljenijih sela brzo kultivizirale i emancipirale, a to i jeste ono najbitnije. (s. n. 1969)

Može se zaključiti kako je tvornica, zahvaljujući sustavnim politikama obrazovanja, zdravstvene skrbi i aktivnog provođenja slobodnog vremena, u velikoj mjeri utjecala na emancipaciju žena sinjskog kraja.

\footnotetext{
13 Isto.

${ }^{14} \mathrm{~S}$ vremenom će se situacija ipak promijeniti. Žene su postale aktivnije u sportu, pa je tako Rukometni klub Dalmatinka bio jedini ženski sportski kolektiv u Sinju. Tradicija ženskog rukometa održala se do danas.

${ }^{15} \mathrm{O}$ utjecaju tvornice Dalmatinka na emancipaciju žena pisale su Vedrana Premuž Đipalo, Chiara Bonfiglioli, Marina Perić Kaselj i Rebeka Mesarić Žabčić.
} 


\section{STAMBENA POLITIKA TVORNICE I URBANIZACIJA SINJA}

Stambena politika Dalmatinke znatno je utjecala na životni standard radnika i urbanizaciju samog grada Sinja. Provodila se planski i već su pedesetih godina prošlog stoljeća izgrađeni prvi stambeni objekti. O tome saznajemo iz prepiske tadašnjeg direktora Dalmatinke Miloša Stanojevića s Arhitektonskim projektnim zavodom iz Zagreba, koju nalazimo među Dalmatinkinim Spisima u Državnom arhivu u Splitu. U Spisima se nalaze molbe za stanove koje su radnici Dalmatinke slali Upravnom odboru, uz priloge poput Zapisnika o pregledu stana ili Izvještaja sanitarne inspekcije. Gotovo iz svake molbe vidljivi su loši uvjeti stanovanja i neadekvatni higijenski uvjeti - vlaga, skučenost prostora s obzirom na broj ukućana te izostanak sanitarnog čvora.

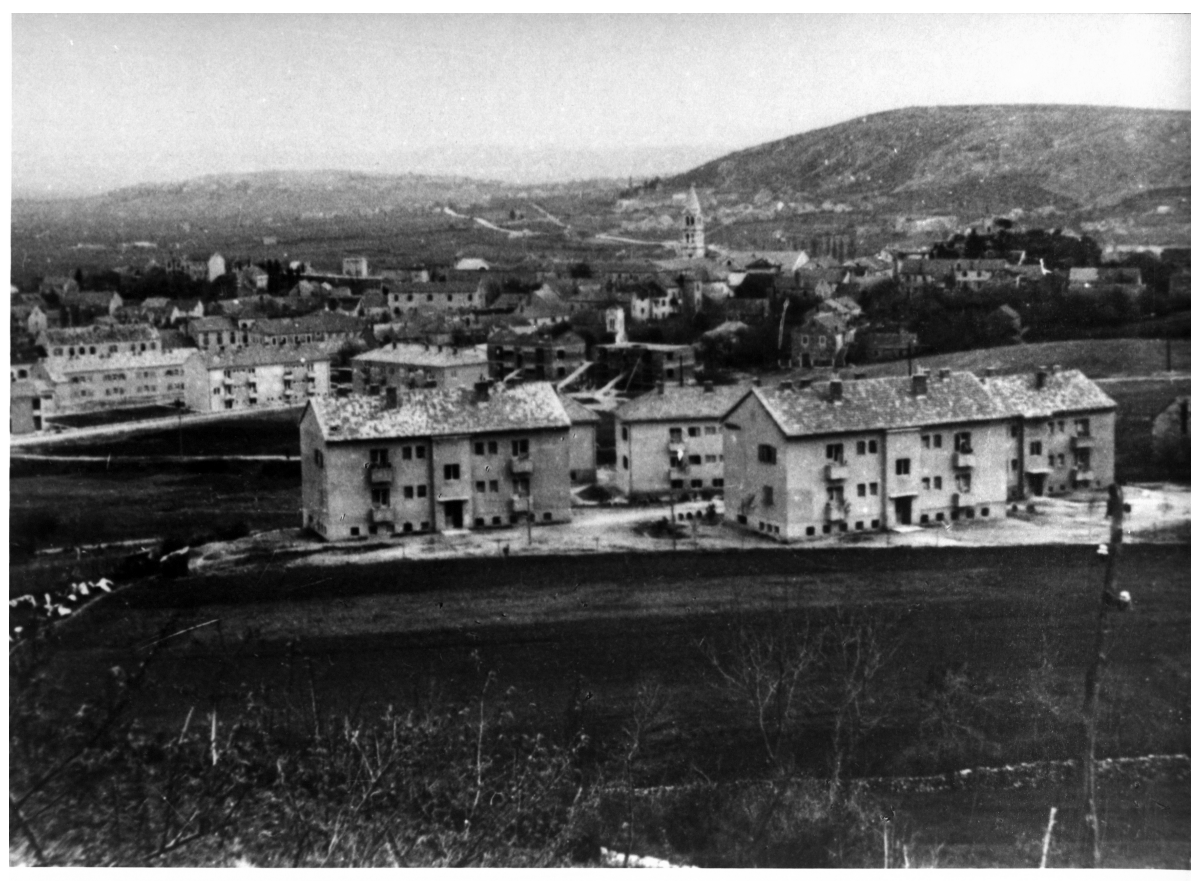

Radnički stanovi tvornice - Tzgraden je skoro jedan novi Sinj. ̌̌ivotni standart naših radnih ljudi i u ovom kraju naglo se.

"Radnički stanovi tvornice - Izgrađen je skoro jedan novi Sinj. Životni standard naših radnih ljudi i u ovom kraju naglo se uzdiže". Izvor: Muzej Jugoslavije, Beograd. Autor fotografije nepoznat

A. R. sa ženom i petero djece. Sedmeročlana obitelj u malom stanu od svega dvije prostorije, koje su u dotrajalom stanju. Stan ne posjeduje ni klozet, ni vodu kao ni bunar ispred kuće. (Molba za stan, 22. 9. 1958.) ${ }^{16}$

${ }^{16}$ DARH-ST, Dalmatinka, Spisi, I /VII (1953. - 1962.). 
Uz molbe radnika, u kojima navode svoj status i uvjete stanovanja, priložen je i obrazac komisije s rubrikama:

- dodijeljeni bodovi,

- može li se koristiti postojeći stan u kojem radnik živi (opcije da i ne),

- opis prostorija,

- ostale okolnosti.

Uz neke molbe priložene su i preporuke sanitarne inspekcije:

nehigijenski je i neprikladan za stanovanje [stan], jer je vlažan, sa dotrajalim podom, neokrečenih zidova a stropa nema. Osim toga stan ne posjeduje ni klozeta, kao ni vodovodnu vodu [...]. ${ }^{17}$

Velik broj radnica doselio je iz obližnjih sela u grad kako bi bile bliže svojem radnom mjestu. Nažalost, smještajni su kapaciteti u Sinju bili jako ograničeni, pa su neke od njih bile primorane živjeti u neljudskim uvjetima:

Možete pretpostaviti kako je nezgodno spavati na hodniku poslije treće smjene. Kad se ne možeš odmoriti, kad gazdarica mora 20 puta najmanje i njena obitelj da prođu hodnikom. (Molba za stan, A. DŽ. 1959.) ${ }^{18}$

Iz sljedećih dviju molbi može se dobiti uvid u uvjete stanovanja u užoj gradskoj jezgri Sinja pedesetih godina.

Živim u zajednici sa mužem i dvoje male djece u samo jednoj sobici u Litrinu oboru. Kuća u kojoj stanujem je jedna od najstarijih u Sinju, potpuno dotrajala, bez plafona i dasaka, puna baja i ostalih insekata koje po cijelu noć lizu u kolonama jedna za drugom. Kuća je toliko dotrajala i istrošena da su joj cigla i zidovi dotrajali, te prilikom kiše čitavu noć ne mežemo da spavamo, jer smo prinudjeni da premiještamo krevet iz jednog kraja sobe u drugi. (Molba za stan, N. M., 4. lipnja 1959.) ${ }^{19}$

Stan u kojem stanuje imenovani D. M., sa suprugom, dvoje djece i još jednim članom porodice, staricom od preko 70 godina, sastoji se iz dvije sobe i kuhinje. Stan se nalazi u dvorištu vlasnika zgrade Videka Zvonke, koje dvorište je zagađeno stokom i u kojem su smještene štale za stoku. U prizemlju zgrade u koje je smješten stan nalazi se štala i konoba. Dakle sama lokacija stana ne odgovara higijensko stambenim uslovima a s obzirom da se u dvorištu igraju javno i balote, stanar D. M. prikraćen je u osnovnim higijenskim mjerama korištenja stana, jer balotaši remete mir ovih stanara. Nemoguće je i sušenje veša u dvorištu zbog zauzetosti istog od strane igrača balota. Nemoguće je i zračenje stana naročito za vrijeme sušnih i ljetnih dana, zbog oblaka prašine koji se dižu uslijed igranja balota. Stan ne posjeduje ni svoj vlastiti klozet, nego postojeći potpuno nehigijenski klozet koji se nalazi smješten na djubrištu u dvorištu služi i za igrače balota, ili se pak dvorište zagađuje ljudskom mokraćom, od strane igrača balota, tako isto od

\footnotetext{
${ }^{17}$ Isto.

18 Isto.

${ }^{19}$ Isto.
} 
ljudi koji dovode stoku u štalu iznajmljivanje a koja se kako je naprijed spomenuto nalazi u prizemlju iste zgrade u kojoj je stan. (Iz Zapisnika o pregledu stana sa preporukom) ${ }^{20}$

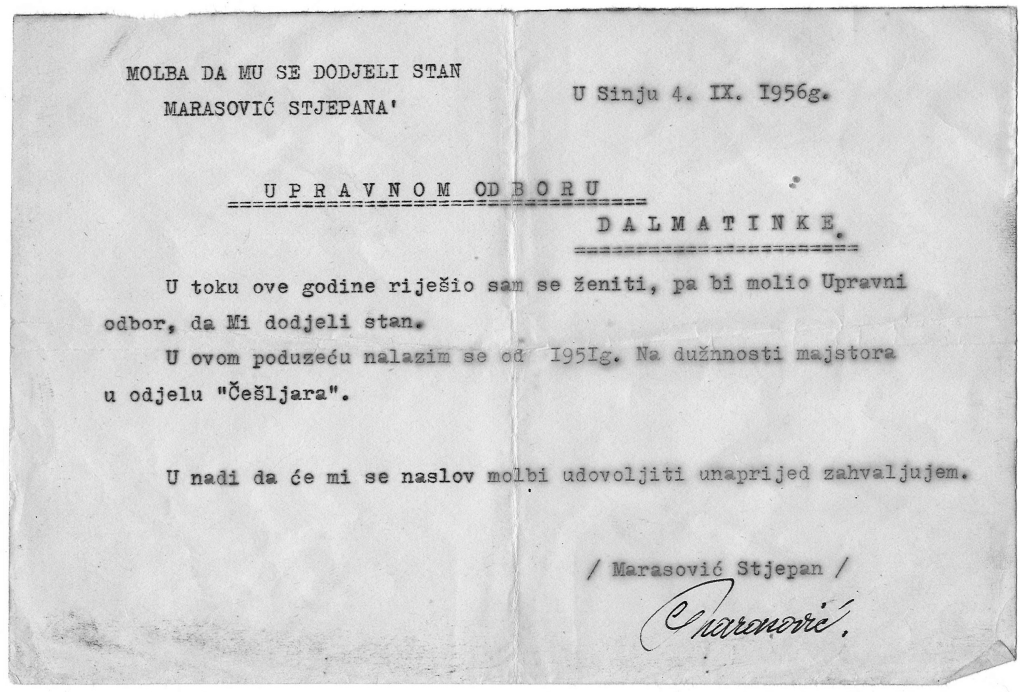

Molba za stan. Iz privatnog arhiva Dunje Marasović, 4. rujna 1956.

Molbe su se ispostavile i kao vrijedan izvor informacija o nekadašnjim lokacijama danas već zaboravljenih ugostiteljskih objekata u gradu. ${ }^{21}$

U periodu od 1955. do 1981. godine izgrađena su 224 stana i 18 samačkih soba. Zahvaljujući povoljnim kreditima brojni su radnici izgradili obiteljske kuće i prilazne puteve, čime se u potpunosti promijenila urbanistička slika grada i okolice kao i životni standard stanovnika. Jedna od prvih Dalmatinkinih zgrada bila je namijenjena radnicima koji su dolazili na rad iz drugih krajeva tadašnje Jugoslavije (Tetova, Duge Rese). Iz korespondencije direktora Dalmatinke s Arhitektonskim projektnim zavodom u Zagrebu doznajemo da se dotičnom arhitektu Bartuliću šalje visinska snimka novog terena za izgradnju stambenih zgrada: "Mi želimo da na uglu Vrličke ulice i Odrine bude zgrada za samce."22 Ta zgrada, koja se nalazi u samom centru grada, i danas se u žargonu naziva samačka jer su nekada u njoj bili smješteni radnici bez obitelji. Nakon samačke, Dalmatinka u neposrednoj blizini gradi zgrade s većim stanovima. Važno je napomenuti da su te zgrade, izvrstan primjer arhitekture modernizma, djelo Lavoslava Horvata, arhitekta čiji je opus, kao i sinjsku epizodu unutar njega, kontekstualizirala i valorizirala Zrinka Paladino (2013). ${ }^{23}$

\footnotetext{
${ }^{20}$ Isto.

21 “Dotični živi u kući Škomrlj Milice, u blizini tvornice Dalmatinka, gdje je donedavno bila gostiona Zadnji dinar" (Iz izvještaja Sanitarne inspekcije/Zapisnik o pregledu stana A. S. A. Isto).

22 DARH-ST, Dalmatinka, Spisi 1/I (1951. - 1953.).

${ }^{23}$ Upućujem na autoričin tekst pod naslovom "Dalmatinka - primjer industrijske arhitekture Lavoslava Horvata", koji se odnosi na Horvatovu sinjsku epizodu, a objavljen je u publikaciji Što je nama naša Dalmatinka dala?, u kojoj je poseban naglasak stavljen na samu arhitekturu tvornice.
} 
Horvat je arhitekt i otvorenog bazena olimpijskih dimenzija čiju je izgradnju financirala Dalmatinka. S pratećim sportskim i društvenim sadržajima te malim, dječjim bazenom znatno je podigao ne samo radnički standard nego i kvalitetu života svim stanovnicima grada.

Gradi se i na drugim lokacijama u užem i širem centru grada, što posljedično utječe na širenje gabarita grada i stvaranje novih gradskih kvartova. Stambena izgradnja, društveni stanovi kao i ulaganje u zajednicu i javne sadržaje učinile su Dalmatinku važnim dijelom recentne lokalne povijesti, ali i nezaobilaznom identitetskom odrednicom stanovnika Sinja i njegovog šireg područja.

\section{IZLOŽBA "ŠTO JE NAMA NAŠA DALMATINKA DALA?" - DAVANJE JAVNOG LEGITIMITETA LOKALNOJ RADNIČKOJ POVIJESTI}

Na izložbi "Što je nama naša Dalmatinka dala?" prezentirani su rezultati istraživanja projekta. Prvi dio izložbe bio je izrazito edukativnog karaktera, i dao je posjetiteljima uvid u povijest i razvoj tvornice i radništva putem info tabli. $U$ drugom su dijelu bili izloženi prikupljeni materijali vezani uz tvornicu - manji strojevi iz tvornice, fotografije radnika, uzorci konca, plakete, umjetničke slike radnika/umjetnika inspirirane tvornicom i radnim procesom, bilteni, dokumentacija.

Info table popraćene su vrijednim fotografijama koje su posjetiteljima pružale ekskluzivan uvid u početke gradnje tvornice. Fotografije su činile dio fotoalbuma koji su radnici Dalmatinke poslali tadašnjem predsjedniku Jugoslavije, Josipu Brozu Titu, i predstavljaju jedan od prvih fotozapisa tvornice i radnog procesa. ${ }^{24} \mathrm{Na}$ fotografijama su prikazani radnici u pogonima kroz procese proizvodnje po fazama - od slaganja bala pamuka u skladištu sirovina, rada na rahljačima pamuka, odjeljenja kardi, češljara do farbaone. Ti su prikazi važni i zbog toga što bilježe procese rada u tekstilnoj industriji koji su modernizacijom nestali. Fotografije su svjedoci radničke povijesti Sinja, početka industrijalizacije i modernizacije Cetinskog kraja. U konačnici, imaju i sentimentalnu vrijednost jer bilježe povijest povezanu s nekadašnjim radom u industriji. Uz Dalmatinku, koja je bila svojevrsni simbol industrije na području Sinja i okolice, svoje pogone su ugasile i ostale tvornice na širem sinjskom području, čime polako u zaborav pada i način rada karakterističan za industrijski period. 25

${ }^{24} U$ fotoalbumu nalazi se posveta: "Značajni uspjesi i opći napredak našega kotara, čija dobra već uživamo, plod su napornog rada i teške borbe kojom vi rukovodite. Šaljemo ovaj poklon sa željom da nam još dugo u zdravlju živite na opće dobro i ponos naših naroda. Narod Kotara Sinj." Fotoalbum se nalazi u fundusu Muzeja Jugoslavije.

${ }^{25} \mathrm{U}$ tom kontekstu važno je istaknuti otkriveni ciklus umjetničkih slika koje su radnici/slikari naslikali povodom proslave tridesete obljetnice rada tvornice. Neda Mandac, jedna od radnica/umjetnica sačuvala je skice prema kojima su nastale spomenute slike. Skice prikazuju žene u njihovim karakterističnim pozama pri obavljanju poslova u pojedinim fazama proizvodnje. Taj slikarski ciklus s pripadajućim skicama umjetnički je doprinos iščitavanju lokalne povijesti radništva, a zanimljiv je i iz aspekta proučavanja fenomena radnika/ 


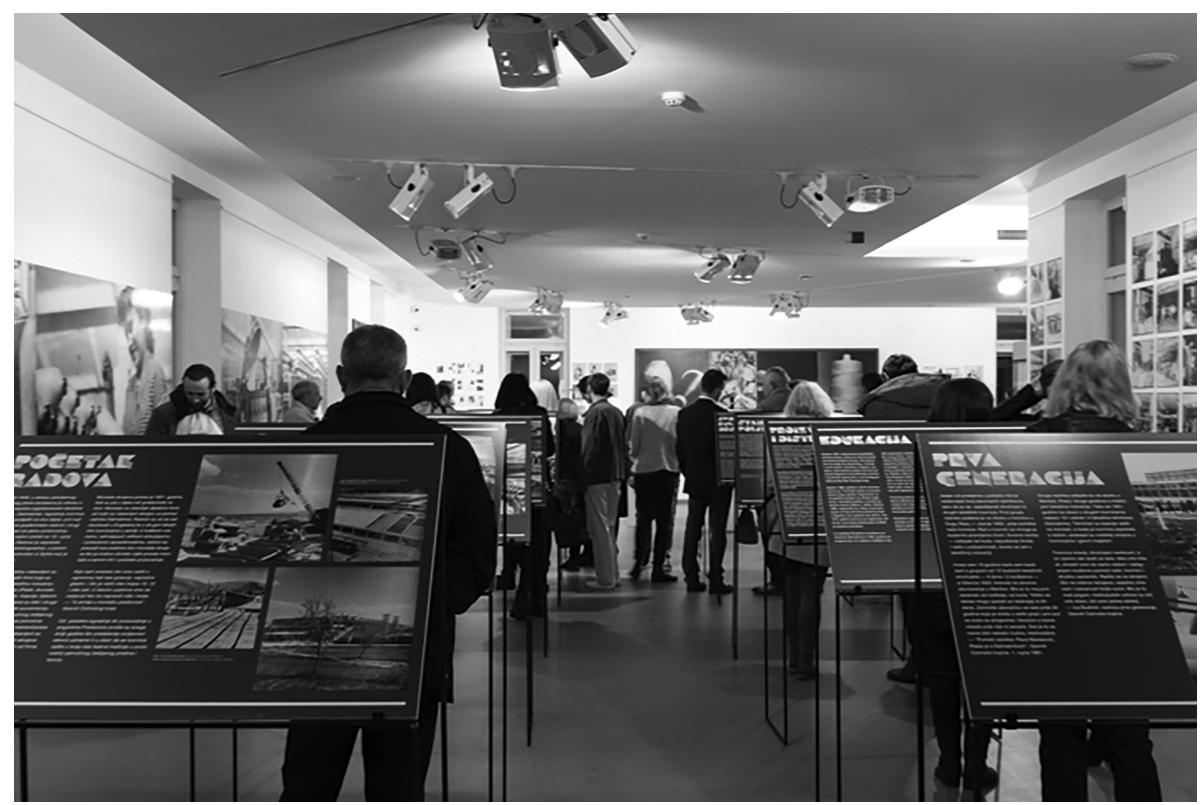

Otvorenje izložbe "Što je nama naša Dalmatinka dala?". Pogled na postav. Fotografija: Zdravko Budimir, 10. 11. 2017.

Izložba završava s dva video uratka, jedan je autentični video bivše radnice, Dunje Marasović, koja je kamerom snimila svoje zadnje trenutke provedene u tvornici, a drugi video rad Neli Ružić simboličnog naziva Do konca. U njemu posljednja radnica Dalmatinke, nekada tekstilna inženjerka, a danas čuvarica praznih postrojenja, gotovo automatiziranom radnjom provlači konac kroz dijelove ugašenog stroja. $U$ videu dominiraju napuštene i devastirane proizvodne hale, koje još uvijek, ogromne i osunčane, podsjećaju na pametnu arhitekturu tvornice koja je bila savršeno prilagođena radnom procesu. $\mathrm{O}$ tome svjedoče i radnice koje se sjećaju kako nije bilo potrebno paliti svjetlo u tvornici. Osvjetljenje danas ima sasvim drugu funkciju, ono omogućava da se kristalno jasno vide uništeni pogoni, prazni hodnici, ugašeni strojevi. U videu Do konca prikazane su ženske ruke, pokreti u prazno na ugašenom stroju, kao svojevrsni ples s mrtvim partnerom. Sva tragičnost može se iščitati iz tog prikaza; ugašena industrija (stroj) i još uvijek živa znanja radnica (ruke), koja su se godinama usvajala kako bi s vremenom postala automatizirana radnja. Ruke u videu predstavljaju ženski princip, radničku i zaboravljenu žensku povijest.

umjetnika. U devastiranim prostorijama tvornice pronađeni su i fotografski negativi na kojima su prikazi vezani uz samu ceremoniju proslave - dodjela diploma, postavljanje i otkrivanje spomenika Josip Brozu Titu, vođenje državnog vrha kroz pogone, prizori iz restorana, razgledavanje izložbe rukotvorina i slika, razonoda u tvorničkom odmaralištu na Perući. 


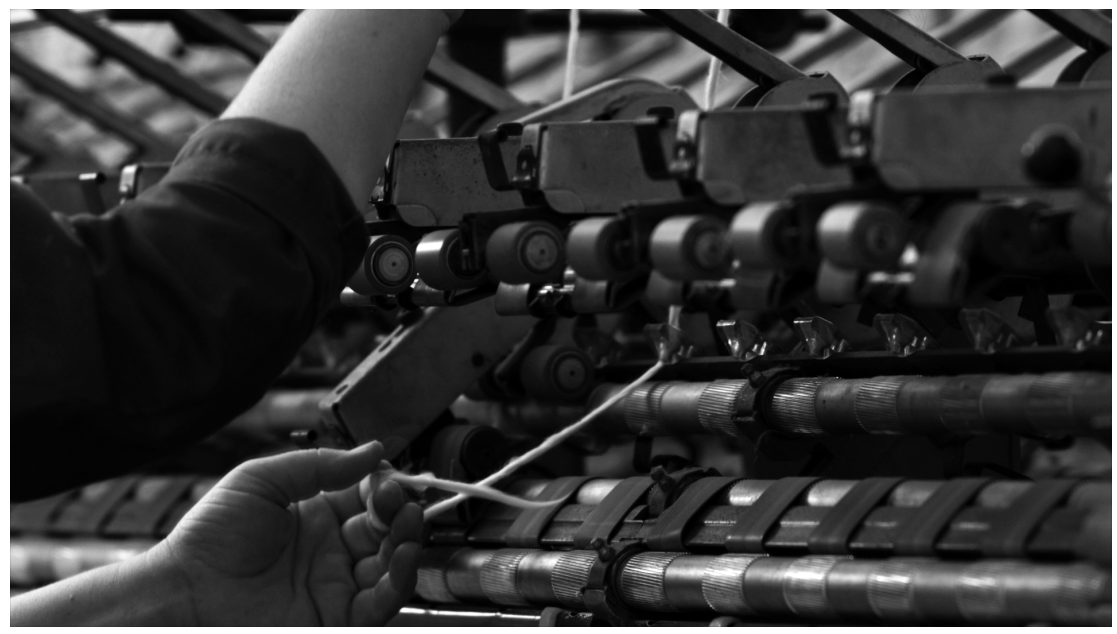

Video still Do konca. Autorica: Neli Ružić

Prvi dio izložbe služi kao svojevrsna uvertira u drugi, u kojem se otvara prostor za kritičko promišljanje, s osvrtom na period propadanja tvornice.

Tijekom trajanja izložbe vodio se Dnevnik dojmova u kojem su zabilježene reakcije bivših radnika kao i članova njihovih obitelji.

Otvorenje izložbe "Što je nama naša Dalmatinka dala?". Posjetitelji promatraju fotografije iz privatnih arhiva radnika. Fotografija: Zdravko Budimir, 10. 11. 2017.

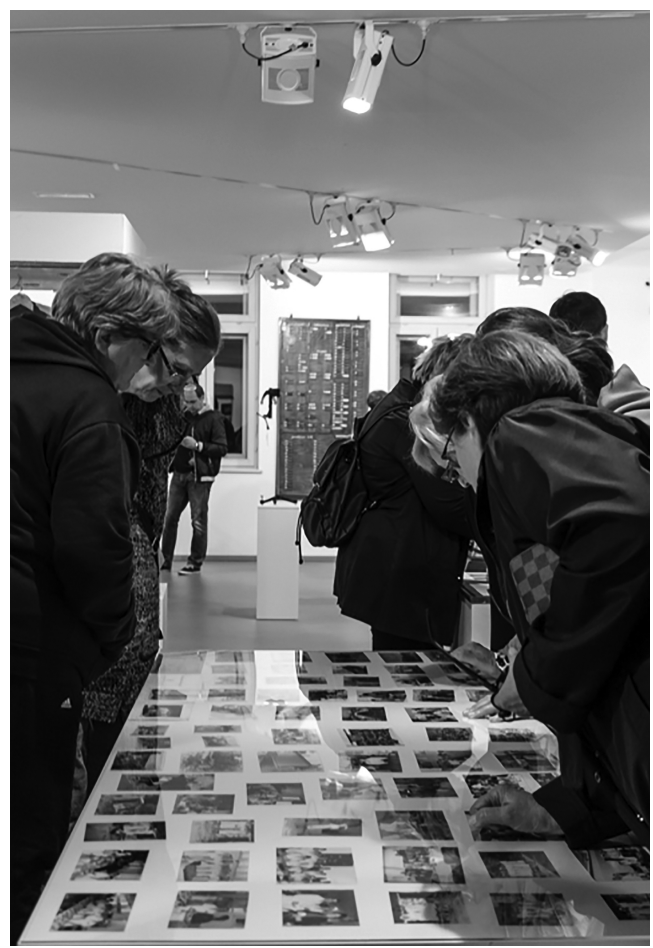


Kćer bivšeg direktora Dalmatinke V. M., došla je preko praznika u Sinj posjetiti izložbu. Živi u Zagrebu. O izložbi je saznala preko Facebook stranice. Studirala je svojevremeno Tekstilno tehnološki fakultet i sjeća se kad bi njen otac došao u Zagreb, uvijek bi se na trgu divio Dalmatinkinoj reklami. Govorio bi - Ma ko ovo ima? Pliva, Kraš i... Dalmatinka. Ona bi ga uvik požurivala - Dobro je ćaća, ajmo. Kaže da je živio za Dalmatinku, da bi često putovao i koji put bi i djecu zanemarivao zbog Dalmatinke. Čudi se kako se bar neka faza proizvodnje nije uspjela održati - Ah, krivi su ljudi... (Iz Dnevnika dojmova, 19. 12. 2017.)

Sićan se kad je Tito dolazio, nosile su se bile kape ne plave... eto to mi je ostalo... Završila sam tri godine Tekstilne (prelac) i nije bilo baš lako, imali smo dnevnik rada, morali smo polagat ispit vezan uz poznavanje rada, sve smo faze prošli u tvornici. Ja sam radila u Končaoni, ali sam često minjala pogone. Kasnije sam završila na pakovanju. Imali smo radne akcije na Perući, u petom misecu smo se kupali u Cetini... Bože šta nam je bilo lipo... pa smo litovali u Strožancu. U tvornici je bio restoran, pa ko je bio samac nije mora ni kuvat. U tvornici smo se svi družili, pomagali. Pivale smo kad bi išle iz noćne pa su mislili da smo se opile. Kad bi sile na piće čalale smo se tko će platiti, a danas, bižimo jedni od drugih... Ko bi išta moga da nije bilo Dalmatinke. (bivša radnica Dalmatinke, 30. 11. 2017.)

Putem izložbe i prezentacije projekta u javnom prostoru, sjećanja radnika dobila su svojevrstan legitimitet. Ukoliko ovaj javni prostor promatramo kao prostor propitivanja dominantnih modela, možemo govoriti o mogućem političkom, transformativnom potencijalu koji se otvara u polju umjetnosti.

\section{O POJMU POLITIČKOG U KONTEKSTU PROJEKTA DALMATINKA}

Projektom Dalmatinka stvorio se prostor za političku subjektivizaciju (bilo da govorimo o bivšim radnicima, članovima njihovih obitelji ili građanima/posjetiteljima izložbe) na nekoliko razina. Prva je razina povezana s društveno-političkim okvirom. U tekstu "Art as Agonistic Intervention in Public Space" Claire Bishop (2012) navodi kako je za razumijevanje demokracije kao političkog okvira važno prihvatiti anatagonističku dimenziju, kao i kontigentnu danost koja je u osnovi društvenog poretka. Shvaćanje ovih pojmova predstavlja ključ za razumijevanje demokracije kao hegemonijskog polja borbe. ${ }^{26}$ Baveći se temom radnica u tekstilnoj industriji na primjerima tekstilnih gradova u Srbiji (Leskovac i Štip), Bonfiglioli (2013) naglašava kako su društvene i ekonomske promjene postsocijalističke tranzicije na području bivše Jugoslavije najviše osjetile žene. Tekstilna industrija koja je sedamdesetih i osamdesetih prednjačila u proizvodnji tekstila i odjeće, nakon ratnih devedesetih, zbog urušavanja tržišta i loše vođenih privatizacijskih procesa, doživljava

\footnotetext{
${ }^{26}$ Suvremeni trendovi ne potiču političko razmišljanje, što je, kako Chantal ističe, usko povezano s hegemonijom liberalizma, koji nitko ne propituje. Taj tip liberalizma karakterizira racionalnost i individualizam te negira mogućnost konflikta, samim tim i antagonizma koji je karakterističan za ljudsko društvo (Mouffe 2008: 7).
} 
kolaps. Socijalna stabilnost tekstilnih radnica kao i rodni režim "zaposlene majke" koji je omogućavao majkama četverosatno radno vrijeme nestaju zajedno sa socijalističkim režimom (Bonfiglioli 2013). Tema radničke prošlosti u javnom diskursu razotkriva pravo lice trenutne demokracije (neoliberalnog kapitalizma) koje se ogleda u položaju radnika (prekarijat), kao i u položaju žena koje su, nakon gubitka posla, bile primorane vratiti se u sferu domaćinstva. Pojam političkog, kako ga definira Chantal Mouffe (2016), usko je povezan s pojmovima hegemonije i antagonizma, što je u potpunoj opreci s dominantnim liberalističkim poimanjem društva kao mjesta univerzalnog konsenzusa zasnovanog na razumu. ${ }^{27}$ Novi društveni poredak i političko uređenje ne ostavljaju prostora za sjećanje na socijalizam, osim u kontekstu totalitarnog režima, što je, na lokalnoj razini, najbolje opisao umjetnik Siniša Labrović performansom Zavijanje ranjenika. U tekstu "Kada spomenici ožive - umjetnost sjećanja u javnom prostoru" (Potkonjak i Pletenac 2011), analizirajući Labrovićev performans, autori navode "da je često prostor prizivanja k svijesti i uspomenama, koji se i javno ozakonjuje $u$ kolektivnom pamćenju, upravo javni prostor. U njemu se kontestiraju, sukobljavaju, natječu, pregovaraju svijesti izazvane uspomene, kolektivno sjećanje i osobne prakse prisjećanja". Na tom tragu može se iščitati i projekt Dalmatinka, kao otvaranje javnog prostora za sjećanje bivših radnika na osobnu, radničku prošlost kao i posredno na politički sistem neodvojiv od nje same. ${ }^{28}$ Shvaćanjem javnog prostora kao mogućeg mjesta sukoba, tj. propitivanja dominantnih modela, otvara se prostor u kojem umjetnost i umjetničke strategije mogu imati važnu ulogu. ${ }^{29}$

Projekt Dalmatinka djeluje u polju umjetnosti, ali je u svojoj osnovi interdisciplinaran i često zalazi u polje etnografije i antropologije. Kao takav, možda bi mogao biti dobar primjer onoga što autori teksta "Revisiting Ethnographical Turn in Contemporary Art", Kris Rutten, An van Dienderen i Ronald Soetaert (2013), navode kao primjer umjetničkog projekta koji nastaje suradnjom antropologa i umjetnika. ${ }^{30}$ Navode, naime, dvije vrste takvih umjetničkih projekata - one koji generiraju antropološke spoznaje te projekte koji nastaju kao rezultat etnografskih istraživanja. Tako možemo govoriti o umjetničkim projektima koji su prezentirani kao etnografsko istraživanje i o etnografskom istraživanju koje je prikazano kao umjetnost. ${ }^{31}$ Hal Foster se u svom tekstu "The Artist as Ethnographer" izrazito kritički

${ }^{27}$ Chantal Mouffe, za razliku od Jürgena Habermasa, koji smatra da je javna sfera (kako on naziva javni prostor) mjesto gdje se može na osnovi racionalnog promišljanja postići konsenzus, smatra kako se u javnom prostoru sukobljavaju različiti hegemonijski projekti. Mouffe se distancira i od Hanne Arendt, koja, koristeći se sličnom terminologijom kao i Mouffe (pojam agonizam), ne prepoznaje antagonizam kao preduvjet za uspostavu bilo kakvog modela pluralnosti i koegzistencije (isto: 10).

${ }^{28}$ Temom Dalmatinke u okviru studije sjećanja bavila se Jozefina Ćurković u svom diplomskom radu Radnička kultura i društveno sjećanje na primjeru tvornice Dalmatinka u Sinju.

${ }^{29}$ Umjetnost u kontekstu spomenute teorije hegemonije može igrati ključnu ulogu, ističe Mouffe, kako u održavanju tako i propitivanju postojećeg simboličnog poretka, zato je njena uloga politička (Mouffe 2008: 11).

${ }^{30} \mathrm{Na}$ interes antrolopologije/etnografije za umjetnost (reprezentacijske prakse) i obratno ukazuju i pojave tzv. zaokreta - etnografski zaokret u umjetnosti i vizualni zaokret u antropologiji i etnografskim istraživanjima - koji se odvijaju gotovo paralelno (Rutten, Dienderen i Soetaert 2013).

${ }^{31}$ Isto: 460-461. 
osvrće na ovakve pojave u umjetnosti upozoravajući na niz problematičnih situacija poput manipulacije od strane naručitelja/institucija, svođenja umjetnosti na isključivo estetsku formu ili muzejsku kategoriju. lako projekt Dalmatinka posjeduje elemente etnografskog istraživanja, ipak je artikuliran prvenstveno u polju umjetnosti, kao društveno angažirani umjetnički projekt. ${ }^{32}$

Uvođenje pojma političkog iz polja filozofije politike u područje umjetnosti (onako kako ga definiraju Rancière i Mouffe) pokazalo se korisnim u smislu širenja postojećeg teorijskog okvira unutar kojeg promatramo ovakve projekte. Ne postoji stvarni svijet izvan umjetnosti, nego samo zadane konfiguracije onoga što nam je dano kao stvarno. Ono što doživljavamo kao realnost uvijek je stvar konstrukcije, kaže Rancière. Praksama fikcije, ${ }^{33}$ kako ih on naziva, prekidaju se i nanovo uspostavljaju veze između znakova/stvari i slika, slika i vremena, znaka i prostora, te se uspostavlja novi okvir zadane realnosti. Ove prakse uspostavljaju nove trajektorije onoga što može biti vidljivo, rečeno i učinjeno. Umjetnost, kao i politika, posjeduje inovativni potencijal kojim se propituju postojeći, zadani modeli dominacije (Rancière 2010). Djeluju u polju neslaganja (dissensus), u kojem rekonfiguriraju zajedničko iskustvo osjetilnog. Upravo su umjetnici ti koji, kako kaže Rancière, strategijama mijenjaju okvire, brzinu i razine na osnovi kojih doživljavamo vidljivo i povezujemo ga s nevidljivim elementima i specifičnim značenjima. Pomoću umjetničkih strategija umjetnici prikazuju ono nevidljivo i propituju samorazumljivost onog vidljivog; prekidajući zadane veze između stvari i njihovih značenja te uspostavljajući nove veze koje dotad nisu bile uspostavljene. ${ }^{34} \mathrm{U}$ projektu Dalmatinka, korištenjem različitih umjetničkih strategija (radionice s radnicama, snimanje videa s radnicama, produkcija umjetničkih radova u suradnji s radnicama kao i afirmacija njihovih stavova putem izložbe $u$ javnom prostoru), kreiran je prostor u kojem su nanovo stvoreni odnosi vezani uz njihovu radničku prošlost, koja je neodvojiva, kako je prikazano u prvom dijelu teksta, od povijesti samog grada. Nanovo su (re)definirani odnosi radnika spram vlastite radničke prošlosti, ali i uspostavljene nove veze u kontekstu odnosa lokalne zajednice prema nasljeđu tvornice i s njom povezanog političkog sustava kao i ženske povijesti. Također, izložba se pokazala ne samo kao prostor legitimacije sjećanja nego i kao prostor transfera znanja sa starijih generacija na one mlađe, koje nemaju predodžbu o radu u proizvodnim pogonima. Izložbu je posjetio rekordan broj posjetitelja, od kojih velik broj srednjoškolaca, koji su kroz priču o tvornici (re)definirali

32 Propala industrija i s njom povezane radničke povijesti aktualna su tema posljednjih godina kako u umjetničkim krugovima tako i u etnografskim/antropološkim. Spomenut ću samo neke: Mreža Solidarnosti, Projekt Željezara Sisak (Festival Željezara), projekt Jugoplastika, projekt Borovo. Upućujem na tekstove Marine Blagaić i Renate Jambrešić Kirin "Ambivalentno nasljeđe socijalističkih radnica: slučaj tvornice Jugoplastika" (2013), tekstove vezane uz projekt Borovo (http://borovo1988.radnickaprava.org/strajkovi, pristup 1. 7. 2018.), tekst Sanje Potkonjak i Tee Škokić "U svijetu željeza i čelika: etnografija rada, nezaposlenosti i nadanja" (2013), istraživanje Nikoline Rusac Pazinka-kulturnoantropološki i muzeološki pristupi tematizaciji industrijskog nasljeđa socijalizma (2014), te tekst Maje Maksić i Andree Matoševića "Kad si opušten, tada možeš dati sve od sebe': etnografija rada u pulskoj Arena trikotaži" (2018).

${ }^{33}$ Fikcija je način na koji se mijenjaju zadani modeli osjetilne prezentacije i oblika izricanja; različitih okvira, razina i dinamike i izgradnje novih odnosa između stvarnosti i pojavnosti, pojedinca i kolektiva (Rancière 2010: 141).

34 Isto: 140. 
svoj odnos prema recentnoj prošlosti i već zaboravljenom političkom sustavu u kojem je jedna tvornica izgradila grad.

S obzirom na veliko zanimanje kao i mobilizirajući efekt koji je izazvan projektom, može se zaključiti da Dalmatinka još uvijek mijenja grad.

\section{NAVEDENA LITERATURA I IZVORI}

Bishop, Claire. 2012. Artificial Hells. Participatory Art and the Politics of Spectatorship. London: Verso.

Blagaić, Marina i Renata Jambrešić Kirin. 2013. "Ambivalentno nasljeđe socijalističkih radnica. Slučaj tvornice Jugoplastika". Narodna umjetnost 50/1: 40-73.

Bonfiglioli, Chiara. 2013. "Gendering Social Citizenship. Textile Workers in Post-Yugoslav States". Dostupno na: http://www.citsee.eu/citsee-study/gendering-social-citizenship-textile-workers-post-yugoslav-states (pristup 1. 7. 2018.).

Bonfiglioli, Chiara. 2017. "Strukture osjećaja nakon Jugoslavije. Slučaj tekstilnih radnika Dalmatinke”. U Što je nama naša Dalmatinka dala? Jelena Pavlinušić, Dragana Modrić i Nikola Križanac, ur. Sinj: Kulturno umjetničko središte, 56-66.

Ćurković, Jozefina. 2018. Radnička kultura i društveno sjećanje na primjeru tvornice Dalmatinka. Diplomski rad. Dostupno na: http://darhiv.ffzg.unizg.hr/id/eprint/10053/1/DIPLOMSKI\%2OEKA_Dalmatinka_\%20dru\%C5\%A1tveno\%20sje\%C4\%87anje\%20i\%20radni\%C4\%8Dka\%20kult.pdf (pristup 7. 7. 2018.).

Dalmatinka - list radnih ljudi predionice i tvornice Dalmatinka, bilten tvornice Dalmatinka. 1969. (br. 4)., 1970. (br. 1, 2, 5), 1977. (br. 1), 1980. (br. 3), 1981. (br. 8), 1982. (br. 14), 1985. (br. 21).

"Dalmatinka nam je otvorila put u život". 1969. List tvornice konca Dalmatinka - Sinj. Sinj: Dalmatinka.

Dalmatinka, Spisi 1/I,II (1951.- 1953), Spisi, I, /VII (1953. - 1962.). Državni arhiv u Splitu.

Foster, Hal. 1995. The Artist as Ethnographer. Dostupno na: https://monoskop.org/images/8/87/Foster_Hal_1995_The_Artist_as_Ethnographer.pdf (pristup 25. 10. 2018.).

Grupa Borovo (Sven Cvek, Snježana Ivčić i Jasna Račić,). “Kome treba poduzeće? Borovo 1988. - 1991.”. Dostupno na: http://borovo1988.radnickaprava.org/strajkovi (pristup 1. 7. 2018.).

"Iz armije u montažu predionice". 1981. Vjesnik Cetinske krajine 2/22: 5.

Magdić, Diana. 2017. “Grad Sinj. Kraj četvrtstoljetne regresije”. U Što je nama naša Dalmatinka dala? Jelena Pavlinušić, Dragana Modrić i Nikola Križanac, ur. Sinj: Kulturno umjetničko središte, 76-79.

Matošević, Andrea i Maja Maksić. 2018. “'Kad si opušten, tada možeš dati sve od sebe'. Etnografija rada u pulskoj Arena trikotaži". Narodna umjetnost 55/1: 95-110. https://doi.org/10.15176/vol55no106

Mouffe, Chantal. 2008. "Art as an Agonistic Intervention in Publice Space". Open 14. Dostupno na: https://monoskop.org/images/1/15/Open_14_Art_as_a_Public_Issue.pdf (pristup 10. 7. 2018.).

Mouffe, Chantal. 2016. O političkom. Zagreb: Politička kultura.

Paladino, Zrinka. 2013. Lavoslav Horvat. Kontekstualni ambijentalizam i moderna. Zagreb: Meandarmedia, HAZU.

Paladino, Zrinka. 2017. "Dalmatinka. Primjer industrijske arhitekture Lavoslava Horvata”. U Što je nama naša Dalmatinka dala? Jelena Pavlinušić, Dragana Modrić i Nikola Križanac, ur. Sinj: Kulturno umjetničko središte, 66-76.

Pavlinušić, Jelena. 2017. “Tvornica i predionica konca Dalmatinka Sinj”. U Što je nama naša Dalmatinka dala? Jelena Pavlinušić, Dragana Modrić i Nikola Križanac, ur. Sinj: Kulturno umjetničko središte, $12-22$. 
Perić, Kaselj Marina. i Rebeka Mesarić Žabčić. 2011. “Žene i industrijska baština. Primjer ‘Dalmatinka’ Sinj”. U Kulturna dediščina industrijskih panog/Industrijska kulturna baština. Ankica Č. Krošelj, Željka Jelavić i Helena Rožman, ur. Ljubljana: Slovensko etnološko društvo, 286-300.

Potkonjak, Sanja i Tomislav Pletenac. 2011. "Kada spomenici ožive. Umjetnost sjećanja u javnom prostoru". Studia Ethnologica Croatica 23: 7-24.

Potkonjak, Sanja i Tea Škokić. 2013. “U svijetu željeza i čelika. Etnografija rada, nezaposlenosti i nadanja”. Narodna umjetnost 50/1: 74-95.

Premuž Đipalo, Vedrana. 2016. “Žene u doba socijalizma. Slučaj ‘Dalmatinka”'. Ethnologica Dalmatica 23/1: 159-192.

"Prve koševe zabile su žene". 1982. Vjesnik Cetinske krajine.

Rancière, Jacques. 2010. Dissensus. On Politics and Aesthetics. Dostupno na: http://artsites.ucsc.edu/ sdaniel/230/Rancière\%20-\%20Dissensus\%20-\%200n\%20Politics\%20and\%20Aesthetics.pdf (pristup 10. 10. 2018.).

Referat sa devete godišnje skupštine sindikalne podružnice Dalmatinke održane 7. 2. 1960. 1960. Iz privatne arhive radnika.

Referat sindikalne podružnice Dalmatinke 1960. godine. 1960. Iz privatne arhive radnika.

Rusac, Nikolina. 2014. Pazinka. Kulturnoantropološki i muzeološki pristupi tematizaciji industrijskog nasljeđa socijalizma. Dostupno na: http://darhiv.ffzg.unizg.hr/id/eprint/6230/1/Rusac\%20Nikolina_Pazinka.pdf (pristup 1. 7. 2018.).

Rutten, Kris, An van Dienderen i Ronald Soetaert. 2013. "Revisiting Ethnographical turn in Contemporary art". Critical Arts 27/5: 459-473. Dostupno na: https://www.tandfonline.com/doi/abs/10.1080/02 560046.2013.855513 (pristup 1. 11. 2018.).

Spomen knjiga u povodu proslave dvadesete godišnjice postojanja poduzeća Dalmatinka - predionice i tvornice konca Sinj: 1951.-1971. 1971. Sinj: Dalmatinka.

Vjesnik Cetinske krajine. 1981./1982. Muzej Cetinske krajine Sinj.

\section{HOW A FACTORY (HAS) CHANGED THE CITY: THE EXAMPLE OF DALMATINKA}

The opening of the Dalmatinka spinning mill and thread factory in the middle of the 20th century marked both the industrial and cultural revolution in the undeveloped and rural area of the Dalmatian Hinterland. As one of the most successful textile factories in Southeastern Europe, Dalmatinka was the initiator of the local economy, and the social and urban development of the town of Sinj. Since its very beginning, Dalmatinka instituted a housing care policy that affected the urbanization of the town. The factory displays the history of workers, housing care policy, infrastructure development of the town, as well as social phenomena such as female emancipation. This article presents an analysis of the results of a study which was conducted within the project "Industrial heritage and memory culture on the example of the Dalmatinka factory - Sinj" and points to the possibility of analysing the project in the context of establishing the political in art as an important element in engaging the public/community.

Keywords: Sinj, Dalmatinka, industrial heritage, the political, socially engaged art practices 